\title{
Türk-İslam Sentezcilerinde Hukuk, Ahlak ve Din İlişkisi
}

\author{
DOI: 10.26466/opus.848373
}

*

\author{
Ahmet Selim Kadıŏlu * \\ * Dr, Ankara Sosyal Bilimler Üniversitesi, Hukuk Üniversitesi, Ankara, Türkiye \\ E-Posta: dr.askadioglu@gmail.com \\ ORCID: $\underline{0000-0003-0877-4513}$
}

\section{Öz}

Hukuk, ahlak ve din birer sosyal kurum olarak birbirlerini etkilemektedir. İslamiyet gibi hayatın her alanına nüfuz etmeyi hedefleyen dinlerde, dinin diğer ikisi üzerindeki etkisi daha belirgindir. Bu nedenle Islam toplumlarında din genellikle ahlakın ve hukukun kaynă̆ı olarak görülmüş̧ür. Devlet yöneticilerinin dinin hukuk ve ahlakla olan ilişkisine dair kabulleri de hukuk, ahlak ve din arasındaki ilişkiyi yönlendirmiştir. Türk-İslam Sentezcileri Türkiye'de yüz yılı aşkın süredir doğrudan veya dolaylı olarak devlet yönetiminde etkinliklerini sürdürmektedir. Dolayısıyla Türkiye'de hukuk, ahlak ve din ilişkilerini açıklamak ve anlamak için Türk-İslam Sentezcilerinin bu konulara dair görüş ve kabullerinin bilinmesi gerekmektedir. Türk-İslam Sentezcilerine göre din, hukuk ve ahlak arasında çok yakın ve göz ardı edilemez bir ilişki ve karşılıklı etkileşim bulunmaktadır. Bu karşıllklı etkileşimde ise dinin hakim bir rolü bulunmaktadır. Bilhassa İslam dini söz konusu olduğunda bu rol çok daha baskındır. Onlara göre ahlak ve hukuk da din gibi ilahi kaynaklıdır. Hatta insanlarm ürettikleri hukuk kuralları dahi kaynakların temelde ilahi iradeden aldıkları için asıl olarak ilahi kaynaklıdırlar. Bu nedenle hukuk sistemlerinin ve kurallarının dine, ama öncelikle İslam'a dayanması insan doğasına ve sosyal gerçekliğe aykırı sayılamaz.

Anahtar Kelimeler: Türk-İslam Sentezcileri, Hukuk ve Din İlişkisi, Ahlak ve Din İlişkisi 
ISSN: 2528-9527

E-ISSN : 2528-9535

Yıl Year: 11

Cilt Volume: 17

Sayı Issue:34

\title{
The Relation between Law, Ethics, and Religion According to Turkish-Islamic Synthesizers
}

\begin{abstract}
Law, ethics, and religion affect each other as social institutions. The influence of religion on the other two is more significant in religions aiming to penetrate all areas of life, such as Islam. For this reason, religion is generally considered the source of ethics and law in Islamic societies. The acceptances of state rulers on the relations of religion with law and ethics have also directed the relation between law, ethics and religion. Turkish-Islamic Synthesizers have been working directly or indirectly in state administration in Turkey for more than a hundred years. Thus, the opinions and acceptances of Turkish-Islamic Synthesizers on these issues should be known in order to explain and understand the relations between law, ethics, and religion in Turkey. According to Turkish-Islamic Synthesizes, there is a very close and undeniable relation and mutual interaction between religion, law, and ethics. Religion has a dominant role in this mutual interaction. This role is much more dominant, especially when it comes to the Islamic religion. According to them, ethics and law are divinely ordained, as is religion. Even the rules of law made by the people are divinely ordained as they take their resources mainly from divine will. Therefore, the fact that the legal systems and rules are based on religion, but primarily Islam, cannot be considered contrary to human nature and social reality.
\end{abstract}

Keywords: Turkish-Islamic Synthesis, Relation Between Law And Religion, Relation Between Ethics And Religion 


\section{Giriş}

Hukuk, ahlak ve din birer sosyal kurum olmaları cihetiyle buyurganlıkları, belirlenmiş normlarının bulunması ve normlarına uyulmadığı takdirde ceza ve müeyyide uygulamaları özellikleriyle birbirleriyle benzeşmekte, birbirlerini etkilemekte ve toplumu yönlendirmektedirler. Bununla beraber bu benzerlik, etkileşim ve yönlendirmenin nicelik ve nitelik olarak boyutları toplumdan topluma, çağdan çağa değişmektedir.

Antropolojik olarak bakıldığında Mensching (2004, s.67-75)'in ayrıntılı olarak izah ettiği gibi, iptidai ve kabile/aşiret sistemine dayalı toplum tiplerinde din, ahlak ve hukuk iç içe geçmiş bir birlik halindeydiler. Daha sonra kabilelerin bir araya gelmesiyle meydana gelen devletleşme, kozmopolit şehirlerin oluşumu ve dünyevileşme ile birlikte bu birlik dağılmıştır. Zira önce, başlangıçta dinin ışığında keşfedilmiş ve yine onun tarafından yönlendirilmiş olan ahlak dinden gittikçe bağımsızlaşmaya başlayarak kendine dindışı müstakil bir alan oluşturmuş, daha sonra da bu gelişmeye koşut olarak hukuk da kendi bağımsız alanını teşkil etmiştir. Ancak bu bağımsızlığın tam bir bağımsızlık olmadığı, karşılıklı etkileşim sürecinde dinin başat konumunun hep var olduğu unutulmamalıdır.

Sözünü ettiğimiz dinin başat konumu, her toplumun kendine özgü karakteri yanında dinlerin bireysel ve toplumsal hayat karşısında kendini konumlandırışına göre de değişmektedir. Bu noktada, bireyin ve toplumun hayattnın her anını kuşatma ve düzenleme idealiyle ve hukuk sisteminin (fıkıh) tam olarak kazuistik bir tekniğe sahip olmasıyla (Mahmutoğlu, 2012, s.141-142) İslamiyet'in, karşılıklı etkileşimde başat konumu tartışılmaz dinlerden olduğu söylenebilir. Gerçekten de İslam ülkeleri hukuk, ahlak ve din ilişkilerinde dinin kesin ya da görece üstünlüğünün çok açık biçimde sergilendiği ülkeler olmuşlardır.

Diğer yandan devlet yönetimini elinde tutanların bu konudaki yaklaşımları da, kanun yapma yetkisi ile ceza ve müeyyide uygulama hakkına sahip olma açısından hukuk, ahlak ve din ilişkilerindeki karşılıklı etkileşim sürecinde belirleyici olmaktadır. Yani bir ülkede yasama ve yürütme erklerini teşkil edenlerin hukuk, ahlak ve din ilişkileri hakkındaki düşünce ve kabulleri ya da benimsedikleri dünya görüşü veya fikir akımlarının ana yönelimleri bize o ülkede bahsettiğimiz karşılıklı etkileşimin mevcut halinin kökenleri ve gelecekte evrileceği muhtemel vaziyetleri hakkında bilgi verebilir. 
Türkiye'de önce bilinçli bir kimlik farkındalığı ve sonrasında savunusu olarak II. Abdülhamid devrinde özellikle "beka" sorunu dolayımında kendisini hissettirmeye başlayan Türk-İslam Sentezi, Tek Parti Dönemi'ndeki-Ziya Gökalp, Mehmet Akif Ersoy gibi şahsiyetler üzerinden dolaylı etkilerini unutmamak şartıyla- pasif dönemi dışında yaklaşık yüzelli yıldır Türk devlet politikalarını etkilemekte ve yönlendirmektedir. Tanzimat devrinde Avrupa'dan alınan kanunlaştırma politikalarına bir tepki olarak değerlendirebilecek olan Ahmet Cevdet Paşa'nın yürüttüğü Mecelle çalışması da İttihat ve Terakki yönetiminde çkarılan Hukuk-i Aile Kararnamesi de bu etkileme ve yönlendirmeni ışığında yapılan dikkat çekici kanunlaştırma faaliyetleridir.

1960'l y yllarda bilinçli ve organize şekilde kendini yeniden göstermeye başlayan Türk-İslam Sentezi, 1970'li yıllara gelindiğinde Milliyetçi Cephe (MC) hükümetleri ile hükümet politikalarını doğrudan etkisi altına almış, 1980'den sonra ise hem ihtilal yönetimi hem de Özal Hükümetleri döneminde devlet politikalarına açıkça yön vermiştir. Günümüzde yine devletin "beka" sorunuyla ilintili biçimde Türk-İslam Sentezinin, "Cumhur İttifakı" olarak hükümet politikalarını belirlemekte ve devleti bizzat yönetmekte olduğu söylenebilir. Dolayısıyla modern dönem Türk düşünce ve siyasi hayatında etkisini v etkinliğini sürekli olarak gösteren Türk-İslam Sentezinin incelenmesi ve araştırılması, geçmişi olduğu gibi günümüz fikir ve politik hayatını da anlama ve açıklamada büyük önem taşımaktadır. (Kadığlu, 2020, s.815-816)

Bilhassa günümüzde devleti yönetenlerin hukuk ve ahlaka ilişkin genel politikaları ile somut uygulamalarını anlamak ve anlamlandırmak, sebeplerini ve düşünsel kökenleri açıklamak için, Türk-İslam Sentezcilerinin dinle hukuk ve ahlak arasındaki ilişkiye dair görüşlerinin, dini perspektiften hukuk ve ahlakın mahiyetlerine dair değerlendirmelerinin, dinin hukuk ve ahlakın kaynağı olmasına dair yorumlarının da incelenmesi ve araştırılması gerekmektedir.

"Türk-İslam Sentezcilerinde Din" adlı doktora tez çalışmamızdan üretilmiş olan bu çalışma da, sözünü ettiğimiz gereklilik çerçevesinde ve geniş anlamda olmak üzere hukuk, ahlak ve din arasındaki ilişkilere yönelik olarak Türk-İslam Sentezcilerinin görüş ve kabullerini konu edinmekte olup bununla sinırlandırılmıştır. Araştırma yöntemi olarak nitel araştırma metodu kullanılmıştır. Türk-İslam Sentezcilerine ait eserler, çalışmamızın konusu ve 
sinırlılıkları doğrultusunda dolaylı gözlem yöntemiyle ele alınmıştır. Literatür taraması yoluyla ulaşılabilen kaynaklar derinlemesine incelenmiş, gözden geçirilmiş ve kuramsal bir derleme ile sunularak yorumlanmıştır.

\section{Din ve Ahlak Arasındaki Yapısal ve İşlevsel Yakınlık}

Din ve ahlak arasında, dinin diğer sosyal kurumlarla ilişkisine oranla daha açık görünen, toplumsal ve bireysel hayatı daha çok etkileyen bir ilişki söz konusudur. Bilindiği gibi vahye dayalı dinlerin temel amacı, ahlaken olgun fertler yetiştirmek ve böylece de ahlaki bir toplum vücuda getirmektir. Nitekim İslam peygamberi Hz. Muhammed'in “Ben ancak güzel ahlakı tamamlamak için gönderildim" sözü bu amacı dile getirmektedir. Özellikle günlük hayatta ahlak ve dinden, birbirleri yerine ikame edilerek bahsedilmesi de din ve ahlak arasındaki çok yakın ilişkiyi gösterir.

Düşünce tarihinde din ve ahlak arasındaki ilişki genellikle iki şekilde ele alınmıştır. Bunlardan biri ahlakı dine bağlayıp din üzerinde temellendirirken (teolojik ahlak), diğeri insanın ahlaki tecrübesinden hareketle dini temellendirmektedir (ahlaki teoloji). Buradan din ve ahlak felsefesinin başat problemlerinden biri olan ve "Euthyphron ikilemi" adı verilen şu soruya ulaşılmaktadır: Acaba bir şey Tanrı istediği için mi iyidir, yoksa o şey zaten iyi olduğu için mi Tanr tarafindan emredilmiştir? Düşünce tarihinde soruya verilen cevaplar üç ana grupta toplanabilir: Ahlak, dine dayanır; ahlak ile din iki ayrı bağımsız alandır; ahlak ile din arasında sebep-sonuç ilişkisinden farklı türden ilişkiler vardır. (Aydın, 1997, s.296-297)

Türk-İslam Sentezcilerine göre din ve ahlak arasında çok yakın bir ilişki mevcuttur. Onlar bu yakın ilişkiyi öncelikle din ve ahlakın kaynaklarındaki aynılıkta ararlar. Buna göre din ve ahlak aynı kaynaktan gelmekte olup her ikisi de insanüstü ve ilahi kaynaklıdır. Din ile ahlak arasındaki bu ortak kaynaklık, peygamberlerin şahsında da kendini göstermektedir. Zira peygamberler dini açıdan olduğu gibi ahlaki açıdan da toplumların önderi ve yol göstericisidirler. (Türk Düşünce Hareketi, 2007, s.97-99)

Güngör (1998, s.28)'e göre, Peygamberler ve onların manevi varisleri kabul edilen veliler, ahlaki kurallarını öncelikle kendi yaşamlarında disiplinle uygulamışlar, ahlaki yaşamın önündeki en büyük engel olan benliklerini ahlakilik konusunda eğitmişler, toplumsal ve bireysel ahlaki idealleri tam anlamıyla özümseyerek hayatlarına düstur yapmışlardır. Üst-ben'in temsil ettiği 
değerleri bütün hayatlarına hakim kılan peygamberler, veliler, aziz denilen insanlar hem dini hem ahlaki olarak toplumların liderleri olmuşlardır ki bu durum din ile ahlak arasındaki çok yakın ilişkinin delillerinden biridir.

Aslında ahlakın da din gibi ilahi ve insanüstü kaynaklı olduğunu söylemek, başka bir açıdan dinin, ahlakın kaynağı olduğunu söylemektir. Çünkü ilahi ve insanüstü alan, özünde dinî alandır. Dolayısıyla ahlakın dinle aynı kaynaktan gelmesi demek, ahlakın dinden veya daha yerinde bir tabirle dinî olandan kaynaklanması demektir. Özellikle toplumsal açıdan baktığımızda insanları bir arada tutan şeyin, onların bir takım manevî normlara, yani ahlâk standartlarına ortak olarak inanmaları olduğunu görmekteyiz. Bu ortak inanç olmadan toplum hayatından söz edemeyiz. Ahlâk normları elle tutulup gözle görülmeyen, sadece inanılan şeylerdir. Mesela tabiatta eşitlik yoktur, eşitlik insanlara ait bir idealdir, bir sosyal ahlâk ölçüsüdür. İşte bu ahlâk ölçülerinin ve normlarını en büyük kaynağı dindir. (Güngör, 1976, s.177)

Ancak Güngör (1998, s.115) ahlaki davranış esaslarının ve ahlak kurallarının pek çoğunun dinden gelmesinin inkar edilemez bir gerçek olduğunu belirtmekle beraber, dinin, ahlaki norm ve ölçülerin tek kaynağı olmadığını, ama en büyük kaynaklarından biri olduğunu özellikle ifade etmektedir.

Din ile ahlak arasında yapısal olarak tanımlayabileceğimiz ortak kaynaktan gelmekten dolayı var olan yakınlığın yanı sıra işlevsel yakınlık da Türkİslam Sentezcileri tarafından, din ve ahlak arasındaki yakın ilişkinin en çok dile getirilen göstergelerinden biri olarak göze çarpmaktadır. Bilhassa toplumsal düzeni temin etme konusunda din ve ahlak aynı fonksiyonu icra ederler. Dini kurumlar ahlaki değerler ve prensipler için temel teşkil ederek sosyal düzeni koruma görevini yerine getirirken; dini ritüeller, törenler ve kurallar da oluşturdukları veya güdüledikleri ahlaki davranışlarla değerler sistemi, grup birliği ve dayanışması oluşturarak bireyi ve toplumu sosyal gerilimler ve tehlikelerden arındırır. (Arslantürk ve Amman, 2000, s.328)

Dini kurumlar, törenler, kurallar gibi sosyolojik açıdan gözlemlenebilecek olan, din ve ahlak arasındaki işlevsel yakınlık ve etkileşim, psikolojik açıdan da kendini göstermektedir. Bu anlamda dinin fertte oluşturduğu Allah korkusu ve sevgisi, inananları suç işlemekten ve suça yönelmekten alıkoymaya yardımcı olarak, toplumsal kargaşa ve kaosun en büyük sebeplerinden ve aynı zamanda neticelerinden biri olan suç unsurunun azalmasına neden olmaktadır. (Arvasi, 1989, s.180-181) 


\section{Ahlakın Diniliği ya da Dinin Ahlakiliği}

Din ve ahlak arasındaki ilişkide Türk-İslam Sentezcilerinin üzerinde durdukları sorunlardan biri de, ahlakın dinden ve dinin yoğurup şekillendirdiği gelenekten soyutlanmasına yönelik düşünce ve teşebbüslerdir. Onlara göre küreselci zihniyet, özellikle laikliği kullanmak suretiyle ve evrensellik söylemleriyle inançlardan ve geleneklerden kopuk, laik ahlak olarak isimlendirilebilecek yeni bir ahlak yaratmanın peşindedir. Ancak binlerce yıllık inanç ve geleneğin ürünü olan ahlakın dinle bağlantısını koparmak, yani ahlakın diniliğini yok etmek mümkün değildir. (Türk Düşünce Hareketi, 2007, s.97)

Zira onlara göre laik ahlak, söylem olarak hatalı ve imkân olarak sorunludur. Laik bir ahlakı düşünmek, ahlakı sosyal kurum olarak kabul etmemek anlamına gelir. Oysa ahlak pratikte, sosyal bir kurumdur ve üstelik toplumun din ve geleneğinden bağımsız değildir. Laik bir ahlak, dinin ve geleneğin d1şında var olacağına göre, her şeyden önce teorik ve felsefi bir disiplin olacaktır. Bu nitelikte bir ahlak ise yalnızca teoride kalacağı ve kolektif şuurdan güç alamayacağı için yaptırım gücüne de sahip olamayacaktır. Böyle işlevsiz bir ahlakın ise hem sosyal hem de bireysel açıdan etkisiz ve anlamsız olacağı ortadadır. Bu gerçeklere rağmen laik bir ahlak oluşturma amacıyla toplumların inanç ve geleneklerine aykırı olan, kolektif şuurla zıtlaşan normların siyasi baskılarla topluma benimsetilmeye çalışılması girişimleri başarısı kalmaya mahkumdur. Bu girişimler yeni bir ahlakın doğuşunu sağlamadıkları gibi, tam aksine toplumlarda mevcut olan ahlaki birikimin ve toplumsal yapının bozulmasına, sosyal kargaşaların ortaya çıkmasına yol açarlar. Toplumun inanç ve geleneklerine aykırı felsefi ve teorik bir ahlak sistemi, kendini ne surette empoze ederse etsin, insanların vicdanını etkilemez ve böyle bir ahlak sisteminin hükümlerini ihlal eden kişiler vicdanlarında kaygı duymaz, vicdan azabı çekmez. Bu nedenle ahlak dine ve geleneğe dayanmak zorundadır. (Arvasi, 1979, s.389-391)

Türk-İslam Sentezcilerince nihayetinde "bir inanç ve düşünce sistemi" (Güngör, 1998, s.19) olarak tanımlanan ahlakın, bu niteliğiyle dinin en temel unsuru olan Allah inancını dışlaması mümkün değildir, yani "Allahsız bir ahlak nizamı kurmak mümkün değildir" (Arvasi, 1989, s.147). Zira "Allah'a adanmayan hiçbir ahlak teorisi, ahlakı gerçekleştiremez. Hiçbir değer ve ülkü Allah'ın yerini tutamaz. İnsanlık kendisini sahte tanrlardan kurtarmahdır. Ahlakm ülküsü olmada ne 
fert, ne toplum, ne sinıf, ne meslek, ne millet, ne de topyekûn insanlik Allah'ın yerini tutabilir" (Arvasi, 1977, s.116).

Diğer yandan Türk-İslam Sentezcilerine göre ahlak nasıl ki bir inanç sistemi olarak tanımlanabilirse, aynı şekilde din de bir ahlak sistemi olarak tanımlanabilir. "Bugün bütün insanlar için geçerli sayabileceğimiz ahlâk kaidelerinin hepsi dinde vardır. Esasen din, kaynă̆ım Tanrı'dan alan bir ahlâk sisteminden ibarettir" (Güngör, 1998, s.117).

Zira en spritüal olanı da dahil olmak üzere dinler, büyük ölçüde birer ahlak sistemidirler. Bu sistem insanın Tanrı ile ilişkisini düzenlediği gibi diğer insanlarla ve toplumla da ilişkilerini düzenlemekte, bu ilişkilerde neyin iyi neyin kötü olduğunu belirlemekte ve öğretmektedir. İnsan topluluklarında dinin çok büyük etkilerinin görülmesinin, toplumsal yapı ve ilişkileri etkilemesinin en önemli sebeplerinden birisi de budur. Hiçbir toplum, ahlaki kurallar olmaksızın yaşayamayacağına göre, dinden uzak yaşaması da düşünülemez. (Güngör, 1998, s.19-20).

\section{Adaletin Sağlanmasında Dinin İşlevi}

Adalet kavramı din, ahlak ve hukukun onu ideal olarak kabul etmesi ve hepsinin de ulaşmak istediği temel hedeflerden biri olması nedeniyle dinin hukuk ve ahlak ile ilişkisinde merkezi konulardan biridir. Türk-İslam Sentezcilerine göre, insanın varoluşunda yer alan ve tatmini içsel bir zorunluluk taşıyan adalet, insanoğlunun tüm çabasına rağmen dünyada tam olarak gerçekleştirilememektedir. Ama öte bir dünyada eksiksiz olarak tahakkuk edeceğine inanılan ilahi adalet, insanın bu manevi tatmin ihtiyacını gidermektedir. İyi niyetle ne kadar uğraşsalar, ne kadar etraflıca düşünüp kanunlar çıkarsalar da insanların adaleti tam ve hatta çoğu zaman yeterli olarak temin edemeyecekleri inkar edilemez bir gerçektir. Dünyada insan eliyle dağıtılan bu eksik ve yetersiz adalete karşı, inananların kusursuz olduğuna ve Tanrı "eliyle" dağıtılacağına inandıkları bir de "ilâhî adalet" kavramı vardır. Tanrı'ya inanan insanlara göre her şeyden önce adil olan Tanrı her yapılanı, niyetleri, işlerin içyüzünü bilir ve görür, kusursuz adaletiyle de herkese yaptığının tam karşılığını, hak ettiğini tam olarak verir. Böylece dinler, hiçbir insanın varoluşsal olarak göz yumamadığı ama düzeltmek kudretinde de olamadığı ada- 
letsizliği Tanri'ya havale edip onun düzeltilmesini isteyerek hem adalet duygusunu tatmin etmiş hem de bizzat kendisinin adaletsizlik yapmamasını güdülemiş olur. (Güngör, 1998, s.108)

Böylece ilahi adalet kavramı, hukuk ile dinin müşterek noktalarının belki de en önemlisi olan adalet fikri ve duygusunun, hem hukuki hayatta hem de dini hayatta bir temel görevi görmesini sağlayan ana unsurlardan biri olmaktadır. Zaten Türk-İslam Sentezcilerine göre adalet, adaletin nihai dayanağ olan ilahi adaletle temellendirilmek zorundadır. Ki böylece hukuki değerler ilahi adalet içinde temelini bulmuş olur ve sosyal hayata yansırken buradan güç alarak hayatiyetlerini devam ettirmiş olurlar. (Sezen, 1998, s. 165)

Dolayısıyla dinler, adalet idealini sadece öteki dünyada gerçekleşecek olan ilahi adalet şeklinde ele almaz. Adaleti bu dünyada da tesis etmek dinlerin en önemli amaçlarındandır. Nitekim dinin insan ilişkileri açısından en çok önem verdiği şey adalet olup, İslamiyet'e göre Allah'ın adil sıfatı, onun en önde gelen sıfatlarından biridir. Bilindiği gibi adaletin gerçekleşmesi için öncelikle insanların, diğer hemcinslerini kendisiyle yaratılıştan eşit görmesi ve kabul etmesi gerekmektedir ki, dinlerin ilk tebliğ ettiği hakikatlerden biri, tüm insanların eşit doğduğu ve yaratılış itibariyle eşit olduğudur. Hiç kimse renk, soy, ülke ve benzeri hiçbir bakımdan diğer insanlardan üstün olduğunu iddia edemez. İnsanlar sadece sorumluluk çağında ve özgür iradeleri doğrultusunda yapmış olduklarıyla iyi veya kötü sıfatına hak kazanırlar. İslam dinine göre her çocuk İslâm fıtratında doğar, yani her insan doğuştan hem eşit, hem de masumdur. (Güngör, 1998, s.115)

Türk-İslam Sentezcilerine göre İslamiyet, adaleti sağlama konusunda diğer dinlerden daha hassas olup, insanların soyuna, mali durumuna, makamına, konumuna veya dini inancına bakılmaksızın eşit olduğunu, sadece insan oldukları için saygiyı ve adaleti hak ettiklerini kabul eder. İslam'da insanların hukukî durumlarını belirleyen, birbirleri arasında kurdukları statüler değil, Tanrı karşısındaki statüleridir ki, Allah'ın kulu olarak herkes birbirine eşittir. Bundan dolayı birini öbürüne üstün tutarak muamele etmek Allah'in kanununa karşı gelmek demek olup, bu prensip sadece Müslümanlar için değil, bütün insanlar için geçerlidir. Bu yüzden hangi inanca sahip olursa olsun tarih boyunca insanlar İslâm ülkelerinde rahat ve huzur içinde yaşamışlardır. Müslüman olmayanların hakkı bir Müslümanın hakkı gibi korunmuş, yoksul 
ve düşük mevkili birinin hakkı kudret sahibi kimselere yedirilmemiş, insanlara soyları ve inançları sorulmaksızın eşit davranılmıştır. (Güngör, 1998, s.116)

Dünya tarihine bakıldığında dünyanın hemen hemen tüm büyük medeniyet ve kültür bölgelerinde ve toplumların büyük çoğunluğunda görülen, eşitsizliğin kurumsallaşmış veya gelenekleşmiş hali olan, adalet duygusunu körelten sınıf farklılıklarının ve buna dayalı olarak ortaya çıkan sosyal kargaşa ve sınıf kavgalarının İslam ülkelerinde ortaya çıkmamış olması da, yine İslam ahlakının adaleti önceleyen bu yaklaşımından kaynaklanmaktadır (Arvasi, 1980, s.104).

İslamiyet insanlar arasında uygulanmasını ve toplumda hakim olmasını istediği adaletin sağlanması ve korunması için pek çok hüküm getirmiş, bu hükümlere dayalı olarak mekanizmalar oluşturmuştur. Bunların başında kul hakkı kavramı gelmektedir. İslam'a göre insanların bir taraftan diğer insanlara, bir taraftan da Allah'a karşı görev ve sorumlulukları vardır. Bunların yerine getirilmemesi veya eksik yapılması suç niteliğinde olup cezayı gerektirmektedir. Hak sahipliği gereği Allah kendine karşı işlenmiş suçları affedebilirken, diğer insanlara karşı işlenmiş suçları yani kul hakkını, adalet prensibi gereği hak sahibi affetmedikçe Allah da affetmez, işlenen suçun karşılı̆̆ı olan cezayı verir. Böyle bir cezayla karşılaşmamak için kul hakkı yememek Müslümanların toplumsal hayatta en fazla sakındıkları hususlardan biridir ki, böylece adaletin sağlanması ve korunması da bizzat suçu önleyerek temin edilmiş olmaktadır. (Güngör, 1998, s.116)

Türk-İslam Sentezcilerine göre ahlak anlayışında toplumsal adalete büyük ehemmiyet veren İslam dini, bireyci ve toplumcu ahlak anlayışlarının arasında bir denge ahlakı benimsemiştir: "İslamiyet'in ahlak anlayışında ne kolektif ruhu ve cemiyeti tanrlaştıran E. Durkhem'ci telakkiyi, ne de Tanr Diyonizos benim, diye çı̆̆lık atarak kendi egosunu tanrılaştırmaya kalkışan Nietzche'ci görüşleri bulabilirsiniz. Íslamiyet'te iyi olan ne ferdin hoşuna, ne de cemiyetin hoşuna giden harekettir; bunlar hoşlansalar da, hoşlanmasalar da Allah için yapılan iş ve harekettir. Yalnız Allah için ve yalnı O'nun rızasını kazanmak için yapılan işler iyidir" (Arvasi, 1979, s.384). Toplum veya bireyden birine değil de bir bakıma her ikisinin temsilcisi olan Allah'a yönelen ahlaki tutum ve davranışlar, İslami ahlak anlayışının denge niteliğini sağlamaktadır. Bu denge, ahlaki normların müeyyidelerinde de ortaya çıkar. Zira İslam ahlakında hem sevgiye hem de korkuya dayalı çift kutuplu bir müeyyide sistemi vardır. (Arvasi, 1979, s.385) 


\section{Din ve Hukuk Arasındaki İlişki}

Hukuk, uyulması zorunlu olan normlar vaz etmesi ve normların ihlalinde uyguladığı müeyyidelere sahip olması açısından ahlak ve dinle benzeşmektedir. Bu benzeşme iptidai toplumlarda çok daha fazlasına, tam anlamıla bir iç içe geçme haline tekabül etmekteydi. Hatta iptidai toplumlar, "sadece birer kült cemaati değil; aynı zamanda teşekkül yolunda olan bir hukuk cemaatidir" (Mensching, 2004, s.67). Aslında din, normlara ve müeyyidelere sahip olma hususunda iptidai toplumlar dışında ve hatta çağdaş dünyada da hukuktan farklı değildir. Farklılık, bu normlara riayetin ve riayet edilmediğinde uygulanacak müeyyidelerin devlet tarafından koruma altına alınıp alınmamasındadır. Arvasi (1979, s.393)'ye göre din ve ahlak da hukuk gibi "baskıcı" karaktere sahip olmak zorundadırlar, zira onlar da hukuk gibi müeyyidesiz olamazlar. Din ve ahlak tıpkı hukuk gibi, kendi şart ve normları içinde, fert ve toplumları kendilerine uymaya zorlarlar, uyulmaması halinde ise kendi ölçüleri ve sınırları içinde cezalandırırlar. Dolayısıyla müeyyidelerin devletçe yerine getirilmesine bakılmaksızın, din ve hukuk arasındaki yaptırım ve baskıcılık açısından benzerlik olduğunu söyleyebiliriz.

Bununla birlikte hukuk sadece bu dünyaya yönelik müeyyidelere sahipken, din her iki dünyaya yönelik müeyyidelere sahiptir ve asıl önem verdiği müeyyideler öte dünya için koyduğu müeyyidelerdir. Dinin uyguladığı yaptrrımlar bazı durumlarda somut nitelikli olsalar da, dinin asıl yaptırımları manevi niteliktedirler. Katolik Hıristiyanlarda olduğu gibi örgütlü bir yapıya sahip dinlerde yaptırım gücü daha kuvvetli ve maddi nitelikli olur. Çünkü kilise, insanı bir kabahatinden ötürü cemaatten çıarabilir. İnsanların din hayatının ancak veya daha çok örgütlü dini yapı vasıtasıyla düzenlendiği dinlerde kişinin cemaatle ve dini kurumlarla ilişkisinin kesilmesi (aforoz edilmek) dinle ilişkisinin de kesilmesi manasına gelir. Tanrı ile olan münasebetlerin daha çok kişisel özellikte olduğu dinlerde Tanrının insandan hoşnut olmaması en büyük müeyyidedir. Çünkü bu dinlerin temel amacı "Allah rızası" denilen şeyin kazanılması, yani Tanrı'ın insandan hoşnut olmasıdır. Bu hoşnutsuzluğun sonuçları genellikle ahiret hayatında cezalandırılmak şeklinde ortaya çıkar. Bununla beraber, dünya hayatında da ilâhî cezaya uğranabilir. Kimi inanç mensuplarının, öte dünyadaki daha şiddetli müeyyidelerden kaçınmak için kendi istekleriyle kendilerine bazı cezalar uyguladıkları görülmektedir. Özellikle Hıristiyanlığın bazı kollarında kendi kendilerine eziyet 
etmek, acı çektirmek suretiyle günahtan arınma gayretlerine çok rastlanur. Müslümanlıktaki kefaret orucunun bu tip bir cezalandırma örneği olduğu ileri sürülebilir. (Güngör, 1998, s.146)

Hukuk ve din arasındaki benzerlikleri vurgulayan Türk-İslam Sentezcileri aslında çok daha başka bir hususu dile getirmek istemektedirler. $\mathrm{O}$ da hukukun temel olarak ilahi kaynaklı olduğudur. İster insanlara ve tüm tabiata hakim olan ezeli ve ebedi kanunlar anlamında olsun isterse aklın insan doğasına dayanarak ortaya çıkardığı kanunlar anlamında olsun, her koşulda hukukun ilahi bir tarafı ve kaynağı bulunmaktadır. Bütün hukuk düzenleri ve normları son kertede ezeli ve ebedi nitelikli ilahi hukuktan kaynaklanmaktadir. (Sezen, 1998, s.164)

Kanun olgusu, Türk-İslam Sentezcilerine göre hukukun dinle olan bağıntısının somut olarak ortaya çıktığı temel durumlardan biridir: "İnsanlı̆̆ın ilk kanunları "İlâhî Hukuk" fikrine dayanyyordu. Buna göre kanunlar insan iradesinin eseri değildi. Tanrı tarafindan gönderilmişti. Bu kanunlar doğrudan doğruya insan yapısı olduğu zaman bile kaynağını ilâhî iradeden almış sayılıyordu. Böylece insanlığın ilk kanunlarn insan-üstü ve evrensel bir karakter taşıyorlardı. Hakikatte bugün bile hukukun insan-üstü kaynağına olan inanç tamamen ortadan kalkmamıştır. İlâhı̂ hukuka inanır veya inanmazsını. Insan iradesinin dışında tabiatın mahiyetinden doğan veya Tanri'dan gelen bir hukukun varlı̆̆ı veya yokluğu bir ispat veya çürütme konusu olamaz. Buna rağmen lâik hukuk sistemlerinin hakim olduğu günümüzde bile ilâhî ve tabî̀ hukuk inançları devam etmekte, birçok hukukçu ve yazar gözünde büyük önem kazanmaktadır. Bunun asıl sebebi kanunlarn bizdeki adalet duygusunu ve ihtiyacın daima eksik bir şekilde tatmin edişidir."(Güngör, 1998, s.108-109)

Kurtkan (1977, s.14-15)'a göre, ilahi hukuk veya tabii hukuk kavramının bir doktrin olarak kurucusu ve geliştiricisi durumundaki düşünürlerin Batılı olmasına rağmen, doktrine yapılan itirazların da yine Batı menşeli olması, hukukun dinle ve özellikle İslam diniyle ilişkisinde önem taşıyan hususları gündeme getirmektedir. Doğu toplumlarında, bilhassa İslam aleminde, böyle bir doktrini öne sürmeye ihtiyaç olmadığı meydandadır. Çünkü bu doktrin ve onun ileri sürdüğü değerler zaten toplumun, bütün insanlığın ve hatta kainatın bir bütün teşkil ettiği esasına dayanan tevhid inancını temel bir iman kaidesi olarak kabul eden ve tevhide aykırı hukuku tabii hukuk saymayan İslamiyet'in özünde mevcuttur. Böyle olunca, İslam toplumlarında Kur'an'ın tevhidle ilgili özünü ortaya koyan, tefsir edip değerlendiren din adamları yetişmiş, fakat onlar bu tabii hukuk düşüncesini bir doktrin olarak 
öne sürmemişlerdir. Hıristiyanlık ise tahrif edilip tevhid inancına dayalı olmaktan çıkarıldığı için, Batı'da tabii hukuk düşüncesini düşünürler ileri sürmek durumunda kalmışlar, fakat topluma mal olmuş kıymet hükümleri halinde, dinden kuvvet almayan tabii hukuk fikrini zamanla Batılı düşünürlerin bizzat kendileri de eleştirir hale gelebilmişlerdir.

Tabii hukukun İslamiyet'in özünde yer aldığı gerçeği, modern hukuk sistemlerinin ana prensipleri incelendiğinde ortaya çıkmaktadır. Modern devletlerin kanunlarına bütüncül açıdan bakıldığında çağdaş resmi hukuk donelerinin özünde ve ruhunda tevhid (yani birlik içinde hayatiyet) esasının bulunduğu görülür. Aynı zamanda İslam'ın özü ve ruhu olan tevhidin, çeşitli dinlere mensup olan ülkelerde, resmi hukukun temelinde yer almakta olduğu söylenebilir. Yani modern ülkelerde, bizzat devletler tarafından inşa edilen hukukun ve hatta devletlerarası hukukun güttüğü temel amaç, halkı çeşitli sosyal grupları, kurumları ve ilişkileri itibariyle bir bütünlüğe, birliğe kavuşturabilmektir. Böylece modern hukuk sistemleri ve normları aslında İslam'a, İslam'ın özüne doğru bir yönelişi ifade ettiği gibi, İslam'ın apaçık izlerini de taşımaktadır. (Kurtkan, 1977, s.174-175)

Nitekim modern hukuk sistemleri tarafından öncelenen ve hayata geçmesi veya korunması için kanunlar çıkarılan şu konular İslamiyet tarafından daha yedinci asır gibi erken bir dönemde vazedilmiştir: Sosyal yardımlaşma ve her vatandaşın orta sınıfa girebilme hakları, insan hakları ve demokrasi, kan davalarının kaldırılması, içki, kumar ve faizin yasaklanarak bunlardan doğan zararların önlenmesi, karaborsaya karşı mücadele, dul ve yetimin haklarının himayesi, kadın haklarının tanınması, çokeşlilikten tekeşliliğe dönülmesi, boşanmaların sınırlamaya tabi olması, kadının ölen kocasına ait terekeye dahil bir mal sayılmasının önlenmesi, hukuk ve mal davalarında kadınerkek eşitliği, kadının çalışma ve çalışarak kazandığını kendine alıkoyma hakkı, kadınların mal ve mülke varis olabilme ve servetinde istediği gibi tasarruf edebilme hakkı ve bunlara benzeyen birçok haklar. (Kurtkan, 1977, s.175)

Kurtkan'a göre sonuç olarak, hukukun özünde İslam'ın özü olan tevhid esasının yer alması, hukukun salt hukuk ve teşri faaliyetinin ötesinde daha genel bir düzenin yansıması olduğunu gösterir. Şöyle ki, İslam ve onun özü olan tevhid, öncelikle ve sadece hukuka saygılı bir toplumu değil, bunun ötesine geçerek İslam ahlakını özümsemiş bir toplum oluşturmak ister. Dola- 
yısıyla en geniş mahiyetiyle İslam ahlakındaki yeni fiil, hareket ve ilişki şekillerini düzenleyen ve devlet yaptırımına sahip hükümler hukuku meydana getirir iken, sırf inanca ilişkin hükümler ahlakın/dinin tamamen manevi kısmını oluşturur. Şu halde, İslam'da fikıh adını alan hukukun, ahlaktan ayrı bir yeri ve mahiyeti yoktur. $\mathrm{Bu}$, geçmişte böyle olduğu gibi bugün de böyledir. Çağımızda da sosyal bir düzen anlamında hukukun, İslami ahlaktan ayrı ve kendine has bir varlığı yoktur. Bu durum, İslam'ın, kurumları arasında ilişkinin olmadığı, parçalanmış, birlik ve bütünlükten yani tevhidden uzak bir toplum yapısına olan uzaklığıyla da doğru orantılıdır. (Kurtkan, 1977, s.210)

Din ve hukuk arasındaki ilişkiyi İslam dini açısından incelerken Kurtkan'ın ideal ve aşkın nitelikte olmak üzere ortaya koyduğu ikili ayrımı Ziya Gökalp'te de kısmi bir benzerlikle bulmaktayız. Gökalp (1994, s.66)'e göre İslâmiyet en başından beri, günümüzdeki hukuk kavramından daha geniş bir alana tekabül eden fıkıh kavramı içinde, bir tarafa sırf dini (diyanî) hükümleri, diğer tarafa da hukuki (kazaî) hükümleri koyarak bunları birbirinden ayırmıştır. Daha İslam'ın ilk asırlarında dini hükümleri bildirmek üzere "müftülük" makamı, hukuki hükümleri bildirmek üzere "kadılık" makamı ayrı ayrı tesis edilmiştir. Hatta önde gelen İslam hukukçularından İmam-ı Azam Ebu Hanife, bu iki makamın birleşmesini caiz görmediği için günümüzde Adalet Bakanlığı olarak isimlendirilebilecek olan "Kadı-i kudat" görevini kabul etmemiştir. İslam hukuk anlayışında bu ikili ayrımın varlığı uygulamada pek çok konuda ortaya çıkmaktadır. Dini açıdan caiz olmayan birçok hususun, hukuki açıdan geçerli olduğu çokça görülür. Örnek olarak şunlar verilebilir: Faiz almak dinen caiz olmadığı halde hukuken alınabildiği durumlar bulunmaktadır. Zaman aşımından dolayı bir hak hukuken düşebilirse de, dinen zaman aşımı söz konusu olmaz. Dinen, varise vasiyet etmek caiz olmadığı halde, hukuken bazı hukuki yollar vasıtasıyla varise vasiyet etmek mümkün olabilmektedir. Eşler arasında adaletle davranılamayacaksa çok evlenme dinen caiz olmadığı halde hukuken adaletle davranılamadığı durumda da çok eşlilik mümkün ve geçerlidir. Dinen boşanma hoş görülmediği halde hukuken böyle bir durum söz konusu değildir.

Dolayısıyla Gökalp (1994, s.66-68)'e göre, İslami uygulamada esasen dini hükümlerle hukuki hükümler birbirinden ayrı olup, bunların yetkili makamları da birbirinden ayrıdır. Müftüye başvurulduğunda bir işin, sadece başvurucu açısından bağlayıcı olacak dini hükmü alınır, hakime başvurulduğunda 
ise herkes için bağlayıcı olacak mahkeme hükmü, ilamı alınır. "Diyanî hükümlerle kazâ̂ hükümler arasinda bu kadar derin uçurumlar mevcut" olup bu iki makamın birleştirilmesi İslami uygulama açısından bakıldığında aslında bilinenin aksine uygun değildir. Zira bir işin dini yönü, doğası gereği kutsal olduğu için oraya idare-i maslahat, uzlaştırıcılık gibi dünyevi tedbirler giremez. Bir işin hukuki yönü ise ekonomi, tıp, fen gibi birçok dünyevi gerekliliğe uymak zorundadır. Dini ve hukuki yönler birbirine karıştığı zaman sosyal açıdan sorunlar çıkar, çünkü bunların esasları ayrı ayrı amaçlara yönelmiştir. Nitekim İslam toplumlarında bilinenin aksine hem dine karşı hem de hukuka karşı genel bir kayıtsızlık ve özensizliğin olmasının nedeni de budur. Bununla beraber aslında tüm bunlar, din ile hukuk arasında mevcut olan çok yakın ilişkinin varlığını ortaya koymaktadır.

\section{Sonuç}

Toplumsal yapı ve ilişkileri düzenleyen ve yönlendiren hukuk, ahlak ve dinin bizzat kendileri de toplum ve toplumsal olan tarafından yönlendirilirler. Konumuz açısından daha açık bir ifadeyle söylersek, bu üç sosyal kurum birbirleriyle karşılıklı etkileşim halinde bulundukları gibi, diğer sosyal kurumları etkiler ve onlardan etkilenirler.

Diğer sosyal kurum dediklerimizin başındaysa devlet gelmektedir. Devletin bu üç kurumdan özellikle hukuk üzerindeki etkisi izahtan varestedir. Aslında burada etkiden değil de, oluşturucu ve inşa edici bir rolden bahsetmek daha doğrudur. Ayrıca devletin sadece, yasama, yürütme ve yargı erklerinin üçünü birden içeren geniş anlamıyla değil, bir tek yürütme erkinin kastedildiği dar anlamıyla da hukuk üzerinde bu rolünün var olduğu yads1namaz.

Devlet ise kendi kendine çalışan statik bir aygıt değildir. Elbette her ülke veya toplumun kendine özgü farklı boyut ve niteliklerde statikleşmiş sayılabilecek bir devlet geleneğinden söz edilebilir. Ancak devlet, yönetim mekanizmasını oluşturan idari kadrolardan ve bilhassa en üst kademedeki idarecilerin tutum, kabul ve görüşleri doğrultusunda şekillenen, fonksiyon icra eden, somut politikalarını ortaya koyan bir yapıdır. Hele devletin kurumsal yapısından ziyade, güçlü ve karizmatik liderlerin öne çıktığı toplumlarda devletin kimi zaman tam anlamıyla lider anlamına geldiği de kabul edilmiş- 
tir. Bu durumun en uç örneklerinden birini, Adolf Hitler'in Nasyonal Sosyalist Alman İşçi Partisindeki vekili olan Rudolf Hess'in partinin 1934 yılındaki kongresinde yaptığı konuşmada söylediği şu sözlerde buluruz: "Parti Hitlerdir, Hitler Almanya'dır, Almanya ise Hitler'dir."

Demek ki devleti yönetenlerin dünya görüşleri norm koyucu niteliği nedeniyle başta hukuk olmak üzere tüm sosyal kurumları etkilemektedir. Ahlak ve din de bu etkiden azade olmamakla birlikte, bu ikisinin insanın zihniyetini oluşturmadaki büyük etkisini düşündüğümüzde, özellikle dinin etkilenmekten çok etkilediğini söylemek zorundayı. Dolayısıyla bir toplumda yönetici tabakanın din anlayışları, dinin hukuk ve ahlakla olan ilişkisine bakışları, hukuk ve ahlak üzerinde dinin etkilerine dair kabulleri, o toplumda hukuki ve ahlaki yapıyı anlamak ve açıklamak için anahtar rolündedirler. $\mathrm{Bu}$ açıdan bakıldığında yüz yılı aşkın süredir Türk siyasi ve fikir hayatı üzerinde etkisini gösteren, yaklaşık son elli yıldırsa bu etkisinin daha çok doğrudan olduğu gözlemlenen Türk-İslam Sentezi üzerine inceleme ve araştırma yapmak büyük önem taşımaktadır.

Türk-İslam Sentezcilerine göre din, hukuk ve ahlak arasında çok yakın ve göz ardı edilemez bir ilişki ve karşılıklı etkileşim bulunmaktadır. Bu karşılıklı etkileşimde ise dinin hakim rolü bulunmakta olup, bilhassa İslam dini bahis mevzuu olduğunda bu rol çok daha baskındır. Ahlak ve din ilişkisine bakıldığında, öncelikle din ve ahlak aynı kaynaktan gelmekte olup her ikisi de ilahi menşelidir. Peygamberler ve veliler de hem dini hem de ahlaki önderdirler. Ayrıca ahlak ve dinin toplumsal gerilim ve sorunları azaltmak gibi temel işlevsel benzerlikleri de bulunmaktadır. Kısaca ahlak dinden kaynaklanır, din de nihayetinde bir ahlak sistemidir.

Onlara göre ahlak, hukuk ve din ilişkisinde öne çıkan ortak kavramlardan biri olan adaletin sağlanmasında da dinin vazgeçilmez bir rolü vardır. Bu üç sosyal müessese, koydukları kurallarla adaletli bir toplum yapısının, adil bir dünyanın oluşmasını temin etmeye çalışmaktadırlar. Ancak bu dünyada mutlak adaletin sağlaması mümkün değildir. İnsanlardaki adalet duygusunun tatmin edilemediği bu dünyada din, getirdiği ilahi adalet anlayışıyla bu duyguyu tatmin etmektedir. Özellikle İslam toplumlarındaki kul hakkı kavramına gösterilen mübalağalı önemin sebebi de bu noktada aranmalıdır.

Türk-İslam Sentezcileri bilhassa norm koyma ve bunların ihlalinde ceza ve yaptırım uygulama özellikleriyle din ve hukuk arasındaki benzerliğe ve etkileşime vurgu yapmaktadırlar. Buradaki öne çıkan fark, hukukun sadece 
bu dünyaya yönelik ceza ve yaptırımları söz konusu iken, din hem bu dünya hem de öteki dünyaya yönelik ceza ve yaptırımlara sahiptir. Bununla beraber onlara göre din ve hukukun her ikisi de temelde ilahi kaynaklıdır. İnsanların ürettikleri hukuk kuralları, kanunlar dahi kaynaklarını doğrudan veya dolaylı yollarla ilahi iradeden aldıkları için asıl olarak ilahi kaynaklıdırlar. Öyleyse Türk-İslam Sentezcilerinin ilahi/tabii hukuk doktrinine yakın oldukları söylenebilir.

Özellikle din ve hukuk ilişkilerinde İslamiyet söz konusu olduğunda din ve hukukun iç içe geçmiş, daha doğrusu dinin hukuku büyük oranda massetmiş olması Türk-İslam Sentezcilerinin konuya dair kabullerini şekillendirmektedir. Aslında onlara göre insan tabiatını önceleyen, insanın doğasına aykırı olmayan her hukuk sistemi esasında İslam'ın özüne doğru bir yöneliştir. Bu nedenle hukuk sistemlerinin ve kurallarının dine, ama öncelikle İslam'a dayanması insan doğasına ve dolayısıyla sosyal gerçekliğe aykırı sayılamaz. Zira dinler hem insanüstü niteliğe hem de toplumsal niteliğe sahiptirler; "Bir hukuk sisteminin dine dayanması, onun sosyal temele dayanmadiğın göstermez. Çünkü din en büyük sosyal müesseselerden biridir" (Güngör, 1998, s.122).

Sonuç olarak 1970'li yıllardan itibaren devleti bizzat yöneten veya yönetmeye ortak olan, Milliyetçi Cephe (MC) hükümetleri, 12 Eylül yönetimi ile onu takip eden Özal hükümetleri ve günümüzde Cumhur İttifakı aracılığıyla Türk-İslam Sentezcilerinin görüşleri hem günlük politika üretmede, hem bu politik birikimle bir siyasi gelenek oluşturmada hem de böylece ülkenin siyasi ve toplumsal geleceğini belirlemede yönlendirici olmuştur ve olmaya devam etmektedir. Dolayısıyla Türkiye'de hukuk, ahlak ve din ilişkileri de bu yönlendirici etkinin altında şekillenmektedir. İşte Türk-İslam Sentezcilerinin hukuk, ahlak ve din arasındaki etkileşim ve ilişkilere dair görüşlerini incelediğimiz bu çalışma, genel anlamıyla "hukuk"un felsefesi ve sosyolojisine değil, son dönem Türkiye'sinin "hukuku" nun felsefesini ve sosyolojisini anlamak için düşünsel kökenlere yönelik bir projeksiyon sunmaya odaklanmıştir. 


\title{
EXTENDED ABSTRACT
}

\section{The Relation between Law, Ethics, and Religion According to Turkish-Islamic Synthesizers}

\author{
Ahmet Selim Kadığlu \\ Social Sciences University of Ankara
}

\begin{abstract}
,As the law, morals and religion are social institutions and similar to each other in terms of peremptoriness, having designated norms and penalty and sanction practices when the norms are not followed; thus, they affect and direct each other. On the other hand, these three affect and direct the society, social structure, and relationships as well as getting affected and directed by the society and their social aspects. Therefore, as three social institutions are in mutual interaction with each other, they affect and get affected by other social institutions and the society. The quality and quantity of this similarity, interaction, and direction change among societies and through the ages.

While religion, morals, and law were intertwined in community types based on primitive and tribal systems, this unity disintegrated with the nationalization of the tribes, the formation of cosmopolitan cities, and secularization. Morals, which were discovered in the light of religion at first and also directed by it, started to gradually become independent of religion and formed a secular distinct field for itself. Later, the law formed its independent field in parallel with this development. However, it should be remembered that this independence is not total independence, and the dominant position of religion always present in the mutual interaction process.

The abovementioned dominant position of religion changes based on the positioning of religion in the face of individual and social life in addition to its specific character. At this point, it can be stated that Islam is among the religion with an unquestionable dominant position in the mutual interaction as it has the ideal to surround and regulate each moment of the individual and social life. Its legal system (fiqh) has a complete casuistic technique. Islamic nations have become countries where the exact or relative superiority of religion is clearly displayed in legal, moral, and religious relationships.
\end{abstract}


Nationalization is an important threshold in the abovementioned process of becoming independent from one another. Then, the state as a social institution has entered into the process of interaction with these three especially law more than other social institutions. The attitudes of those holding the state government in terms of having the rulemaking power and the right to implement penalties and sanctions are determinant in the mutual interaction process in the law, morals, and religious relationships. The opinions and acceptances or adopted world view or main orientations of movements of thought of those with the legislative and executive power in a nation about morals and religious relationships inform us about the origins of the current state and future possible conditions of the mentioned mutual interaction in that nation.

World views of the state governors affect all social institutions especially the law due to their norm-making quality. Although morals and religion are not safe from this effect, especially religion affects rather than getting affected considering the determinative effect of these two on forming the human mentality. Therefore, the administrative class's religious understandings, perspectives on the relationship between religion, law, and morals, and acceptances regarding the effects of religion on the law and morals in a society have the key role in understanding and explaining the law and moral structure in that society. Thus, it is important to conduct a review and study on Turkish-Islamic Synthesis, which has been effective on Turkish politics and ideas for more than a hundred years and has been observed to have a more direct effect in the last fifty years.

The Turkish-Islamic Synthesis made itself evident via especially the "survival" issue during the reign of Abdulhamid the Second first as a conscious awareness of identity and then as a defense. Provided that its indirect effect through individuals like Ziya Gökalp, Mehmet Akif Ersoy during the OneParty Period is remembered, it affects and directs the Turkish government policies for almost a hundred years except for its passive period. The Mecelle (the civil code of the Ottoman Empire) works carried out by Ahmet Cevdet Pasha as a reaction to legalizing policies obtained from Europe during the Tanzimat (reforms) era and Hukuk-i Aile Kararnamesi (Ottoman Legal Family Decree) issued in the Union and Progress Government (Ittihad ve Terakki) are among remarkable legalizing activities performed in consideration of this influence and direction. 
The Turkish-Islamic Synthesis revealing once again in a knowing and organized way in the 1960s took hold of the Nationalist Front governments and government policies in the 1970s. It openly directed state policies both in the revolution government and Özal Governments after the 1980s. It can be stated that the Turkish-Islamic Synthesis determines the government policies and administrates the state personally about the "survival" issues of the state in today's world as the "Public Alliance." Therefore, it is important to analyze and investigate the Turkish-Islamic Synthesis, which is effective and active in the modern period of Turkish idea and political life, to understand and explain the idea and political life of today's world like in the past.

According to the Turkish-Islamic Synthesists, there is a very close and unignorable relationship and mutual interaction between religion, law, and morals. Religion has a dominant role in this mutual interaction and when it comes to Islam, this role is so much more dominant. According to them, religion is essential to secure justice, which is one of the prominent common concepts in the relationship of morals, law, and religion.

In conclusion, the opinions of Turkish-Islamic Synthesists about the relationship between religion, and the law and morals must be known to understand and interpret the general policies and real implementations of state governors related to the law and morals, and to explain their reasons and intellectual origins in today's world. This requires the investigation and examination of Turkish-Islamic Synthesists' evaluation of the qualities of the law and morals from the religious perspective and their interpretations regarding the fact that religion is the source of law and morals. This study is planned due to this requirement and seeks an answer for this requirement.

\section{Kaynakça / References}

Arslantürk, Z. ve Amman M. T. (2000). Sosyoloji: Kavramlar-kurumlar-süreçler-teoriler. İstanbul: Kaknüs Yayınları.

Arvasi, S. A. (1977). İnsan ve insanötesi. İstanbul: Dokuz Işık Yayınevi.

Arvasi, S. A. (1979). Türk-islam ülküsü 1. İstanbul: Türk Kültür Yayını.

Arvasi, S. A. (1980). Türk-islam ülküsü 2. İstanbul: Türk Kültür Yayın.

Arvasi, S. A. (1989). Türk-islam ülküsü 3. İstanbul: Burak Yayınevi.

Aydın, M. S. (1997). Din felsefesi. Ankara: Selçuk Yayınları. 
Gökalp, Z. (1994). Diyanet ve kaza. O. Metehan (hzl.). Ziya Gökalp ve Din içinde (s.6468.). İstanbul: Kamer Yayınları,

Güngör, E. (1976). Türk kültürü ve Milliyetçilik. İstanbul: Ötüken Neşriyat. Güngör, E. (1998). Ahlak psikolojisi ve sosyal ahlak. İstanbul: Ötüken Neşriyat.

Kadıoğlu, A. S. (2020). Türk-İslam Sentezi'nin oluşum ve gelişim süreci. OPUS-Uluslararası Toplum Araştırmalan Dergisi, 16(27).

Kurtkan, A. (1977). Sosyolojik açıdan tasavouf ve laiklik. İstanbul: Kutsun Yayınevi.

Mahmutoğlu, Y. (2012). İslam hukukunun kazuistik yapısı üzerine. S.D.Ü. Hukuk Fakültesi Dergisi, 2(1), 131-151.

Mensching, G. (2004). Dinî sosyoloji. M. Aydın (çev.). 2. Baskı. Konya: Din Bilimleri Yayınları.

Sezen, Y. (1998). Sosyoloji açısından din. 3. Basım. İstanbul: Marmara Üniversitesi İlahiyat Fakültesi Vakfı Yayınları.

Türk Düşünce Hareketi (2007). Türk düşüncesi. 3. Baskı. İstanbul: İrfan Yayımcllk.

\section{Kaynakça Bilgisi / Citation Information}

Kadıoğlu, S. A. (2021). Türk-İslam sentezcilerinde hukuk, ahlak ve din ilişkisi. OPUS-Uluslararası Toplum Araştırmaları Dergisi, 17(34), 15491569. DOI: $10.26466 /$ opus. 848373 